\title{
Iron Overload Pattern in Multiple Myeloma at Diagnosis its Important Clinical Associations
}

\author{
Eylem ELIACIK ${ }^{1}$, Berfu KORUCU ${ }^{2}$, Seda BALABAN ${ }^{2}$, Ayse ISIK ${ }^{1}$, Ibrahim C. HAZNEDAROGLU ${ }^{1}$, \\ Hakan GOKER ${ }^{1}$, Salih AKSU ${ }^{1}$, Nilgun SAYINALP ${ }^{1}$, Yahya BUYUKASIK ${ }^{1}$ \\ ${ }^{1}$ Hacettepe University, Faculty of Medicine, Department of Hematology \\ ${ }^{2}$ Hacettepe University, Faculty of Medicine, Department of Internal Medicine, Ankara, TURKEY
}

\begin{abstract}
As a plasmaproliferative disorder, multiple myeloma (MM) is not expected to cause $\mathrm{IO}$ and actually there are no reports on this condition in MM. In this retrospective study, we evaluated serum iron test results in MM patients at diagnosis in order to find the frequency of IO. Iron overload pattern (IOP) was described as increased transferring saturation (> 45\%) in the presence of normal to increased serum iron and ferritin levels. Among 90 newly diagnosed MM patients (54 male, 36 female, and the median age: 61 years, range: 31-86) IOP was found in 17 cases (17/90, 19\%). There was a close association between lambda light chain type paraproteinemia and IOP (13/17 in IOP cohort vs $26 / 73$ lambda paraproteinemia, $p=0.003)$. Half of the MM patients $(7 / 14)$ with free lambda light chain paraproteinemia had IOP. The main reason of the elevated TS was increased serum iron level in IOP patients, $144( \pm 71)$ vs $57( \pm 24) \mathrm{pg} / \mathrm{ml}(\mathrm{p}<.001)$. Four out of $17 \mathrm{IOP}$ patients had extramedullary involvement and this was significantly more frequent than the other patients. Although high International Staging System risk disease (stage 2 or 3 ) was more frequent in IOP patients $(15 / 15$ vs $51 / 68, p=0.03)$, we could not observe any difference regarding treatment response, and survival between these cases and others. In conclusion, $1 \mathrm{O}$ is also not infrequent MM at diagnosis and it has some clinical associations.
\end{abstract}

Keywords: Multiple myeloma, Iron overload

\section{ÖZET}

Myelom Hastalarında Tanı Anında Demir Yüklenme Sıklığı ve Bunun Klinik Önemi

Plazma proliferatif bir hastalık olan multiple myelomun demir yüklenmesine neden olması beklenmediği gibi bu durumla ilgili herhangi bir bilgi bulunmamaktadır. Bu retrospektif çalışmada, multiple myelom hastalarını demir yüklenme sıklığını öğrenmek için tanı anındaki serum demir testleri ile incelendi. Demir yüklenme paterni, normal- yüksek serum demir ve ferritin düzeyi varlığında, transferin saturasyonunun >\%45 olması olarak kabul edildi. Yeni tanı almış 90 MM hastasından (54 erkek, 36 kadın ve ortalama yaş 61, yaş aralığı 31-86 yı) 17'sinde (17/90,\%19)demir yüklenme paterni saptandı. Lambda hafif zincir tip paraproteinemi ile demir yüklenmesi arasında yakın ilişki vardı (13/17 demir yüklenme paterni ve 26/73 lambda proteinemi, $p=0.003)$.Serbest lambda hafif zincir tip MM hastalarının yarısında (7/14) demir yüklenme paterni vardı. Artmış transferin saturasyonu azalmiş total demir bağlama kapasitesinden kaynaklanmıyordu. Total demir bağlama kapasitesi değeri, demir yüklenmesi olan ve olmayan gruplarda benzerdi. Artmış TS' unun asıl nedeni serum demir değerinin artmasıydı $144( \pm 71)$ vs $57( \pm 24)$ pg/ml (p<0.001). Demir yüklenmesi olan 17 hastanın 4' ünde ekstramedüller tutulum vardı ve bu oran diğer hastalardan anlamlı olarak daha fazlaydı. Yüksek ISS(stage 2 ya da 3) skoruna sahip hastalar demir yüklenmesi olan grupta daha sık olmakla birlikte (15/15 vs 51/68, p= 0.03), bu grup ile diğerleri arasında tedavi yanıtı ve yaşam süreleri açısından herhangi bir fark gözlemlenmedi . Özetle; demir yüklenmesi yeni tanı MM hastalarında sıkça görülür ve bazı klinik sonuçları vardır.

Anahtar Kelimeler: Multiple myelom, Demir yüklenmesi 


\section{INTRODUCTION}

Multiple myeloma (MM) is a chronic incurable malignant plasma cell disease. The systemic and/or localized collection of the neoplastic plasma cells may complicate the clinical course of MM with or without bone marrow involvement. ${ }^{1-3}$ The serum ferritin was suggested to be a prognostic parameter of survival as well as disease activity in patients with $\mathrm{MM} .{ }^{4}$ The potential role of the iron in bortezomib-resistance has also been suggested. ${ }^{5}$ Likewise, targeting the human transferrin receptor 1 (CD71) may be effective in the potential experimental therapy in human MM. ${ }^{6}$ Iron overload (IO) may occur in hematologic neoplastic disorders that are associated with ineffective hematopoiesis, such as myelodysplastic syndrome and acute myeloid leukemia. As a plasmaproliferative disorder, $\mathrm{MM}$ is not expected to cause $\mathrm{IO}$ and actually there are no reports on this condition in MM.

The aim of this study is to assess frequency and clinicopathological associations of IO in MM patients at diagnosis. Iron may have a place in the pathobiology of $\mathrm{MM}^{6-11}$ and its management. ${ }^{5,6,11}$ Elucidation of IO in MM may help better understanding the pathobiology of the disease and even better management of the patients.

\section{PATIENTS AND METHODS}

All MM patients who had been followed in Hacettepe University Faculty of Medicine Department of Hematology during last 10 years have been reviewed in order to find cases with available serum iron test, i.e., serum iron, total iron binding capacity (TIBC) and ferritin levels, at diagnosis. Patients with known chronic liver disease, chronic inflammatory disorder or infection within one month of serum iron testing were not included in the study. Transferrin saturation (TS) was calculated by dividing serum iron level to TIBC. Iron overload pattern (IOP) was described as increased TS $(>45 \%)$ in the presence of normal to increased serum iron and ferritin levels 12. In case of decreased TS and ferritin levels and normal to increased TIBC pure iron deficiency (PID) was diagnosed. If serum iron and TIBC levels were decreased and ferritin was normal to increased pure inflammation anemia (PIA) was considered. When TS was decreased but the other tests were not compatible with PID or PIA, the diagnosis was indiscernible between iron deficiency and inflammation (IIDI). Other deviated serum iron test results were considered nonspecific. Categorical and continuous data were compared by the Chi-square and Mann-Whitney U tests, respectively. Survival analyses were done by the KaplanMeier method. Comparison of survival rates was calculated by the Log-rank test. Statistical Packages for the Social Sciences v17.0 (SPSS Inc., Chicago, IL) software was used for statistical analyses.

\section{RESULTS}

Ninety MM patients (54 male, 36 female, median age: 61 years, range: $31-86$ ) fitting to the inclusion criteria were found. There were 17 patients (19\%) with test results compatible with IOP. At least one serum iron test was abnormal in the majority of cases $(69 / 90,77 \%)$. Other iron parameter abnormalities were classified as PID (1/90, 1\%), PIA (20/90, 22\%), IIDI 6/90, 7\%), and nonspecific (25/90, 28\%). Only 2 IOP patients had red blood cell transfusion histories, 1 and 2 units weeks before the admission.

Demographic data, serum iron test results and some disease-related characteristics of IOP cases and other patients are presented in Table 1. Demographic data were similar in IOP cases and others. Median (25-75 percentiles) serum ferritin level was 639 (266-753) $\mathrm{pg} / \mathrm{ml}$ in the IOP patients. TIBC level was similar in the IOP cases and others. The main reason of elevated TS in the IOP cohort was higher serum iron levels (Table 1).

IOP was not associated with nephrotic syndrome or renal dysfunction (Table 1). Marrow dysplasia was not reported in any patient with IOP. Unfortunately, marrow conventional cytogenetic analyses were available in only 4 IOP patients. Two had normal and 2 complex karyotypes. Both complex karyotypes involved chromosome 1 abnormalities.

Mean baseline hemoglobin concentrations were lower in IOP males and females compared to the corresponding genders in the control group. But, this difference was not statistically significant in males. Although IOP females had significantly lower hemoglobin levels this result should be interpreted with caution as only 6 females were present in the IOP cohort. Improvement of hemoglobin concentrations were observed in IOP patients who attained very good partial response or better ( $\geq$ VGPR) on followup (4 females, $10.8 \mathrm{~g} / \mathrm{dl}$ (9.7-11.8) and 4 males, 12.9 (10.7-15.5)). White blood cell and platelet counts were similar in IOP patients and controls (data not presented).

There was a close association between lambda light chain type paraproteinemia and IOP (13/17 vs 26/73 
International Journal of Hematology and Oncology

\begin{tabular}{|c|c|c|c|c|c|}
\hline & \multicolumn{2}{|c|}{ Iron overload patients } & \multicolumn{2}{|l|}{ Other patients } & \multirow[t]{2}{*}{$P$ value } \\
\hline & $\begin{array}{l}\text { Male } \\
(n=11)\end{array}$ & $\begin{array}{l}\text { Female } \\
(n=6)\end{array}$ & $\begin{array}{l}\text { Male } \\
(n=42)\end{array}$ & $\begin{array}{l}\text { Female } \\
(n=31)\end{array}$ & \\
\hline $\begin{array}{l}\text { Demir* } \\
\text { (F: } 37-145 \mu \mathrm{g} / \mathrm{dl}) \\
\text { M: } 59-158 \mu \mathrm{g} / \mathrm{dl})\end{array}$ & $124(108-225)$ & $123(102-142)$ & $58(41-68)$ & $60(35-79)$ & $\begin{array}{l}<.001(\mathrm{~F}) \\
<.001(\mathrm{M})\end{array}$ \\
\hline Hemoglobin (g/dl) & $9.3(7.7-11.3)$ & $8(6.9-9.1)$ & $9.8(8.7-11.3)$ & $9.8(8.6-11.1)$ & $\begin{array}{l}.01(F) \\
0.38(M)\end{array}$ \\
\hline $\begin{array}{l}\text { TIBC }^{\star}, * \\
(228-448 \mu \mathrm{g} / \mathrm{dl})\end{array}$ & $240(195-275)$ & & $233(194-283)$ & & 0.97 \\
\hline Age $^{\star}$ & $59(52-69)$ & & $64(55-72)$ & & 0.44 \\
\hline Albumin* & $3.8(3.7-4.3)$ & & $3.5(3.0-3.9)$ & & 0.01 \\
\hline Beta2-microglobulin ${ }^{\star}$ & $10520(4870-15400)$ & & 5753 (2862-8109) & & 0.01 \\
\hline ISS ${ }^{\star \star \star}$ stage 2 or $3 \#$ & 15 & & 51 & & 0.03 \\
\hline Kappa light chain type & 4 & & 46 & & 0.003 \\
\hline Lambda light chain type & 13 & & 26 & & \\
\hline Soft tissue plasmacytoma(s) & 4 & & 5 & & 0.04 \\
\hline Nephrotic syndrome & 5 & & 15 & & 0.35 \\
\hline Renal failure & 6 & & 21 & & 0.60 \\
\hline \multicolumn{6}{|l|}{$\begin{array}{l}{ }^{*} \text { Median (25-75 percentile) } \\
{ }^{\star *} \text { TIBC: Total iron binding capacity } \\
{ }^{\star * *} \text { International staging system } \\
\# 15 \text { and } 68 \text { IOL and other patients }\end{array}$} \\
\hline
\end{tabular}

lambda paraproteinemia in IOP cohort and others respectively, $p=0.003)$. Half of the MM patients (7/14) with free lambda light chain paraproteinemia had IOP.

Four out of 17 IOP patients had soft tissue plasmacytomas and this was significantly more frequent than the other patients $(5 / 73)(p=0.04)$. IOP patients had higher-risk disease. International staging system (ISS) stage 2 or 3 disease was present in all 15 IOP patients with available data, compared to 51 out of 68 other patients $(p=0.03)$. However, we could not observe any difference regarding treatment response, overall- and progression-free survivals between IOP cases and others (data not presented). This could be due to low patient numbers.

Post-treatment repeat serum iron tests were available in 9 patients with IOP and 1 patient had also serum iron tests (completely normal) 6 months before the diagnosis. 4 patients with responses $\geq$ VGPR showed complete improvement of the iron tests. Three cases with partial myeloma responses showed various responses in the iron tests. One had complete and 2 had partial improvements (i.e. partial improvement in TS and/or residual hyperferritinemia). Two patients with stable to progressive disease under treatment showed no improvement in the iron tests.

\section{DISCUSSION}

An elevated TS level in a patient without liver dysfunction is a sensitive biochemical indicator for IO 12-13. Clinical algorithms for detection of IO usually start with this test. In this study, we found that serum iron tests compatible with iron overload are not infrequent in MM at diagnosis. These results are related to disease activity of MM. IOP in MM has important clinical associations, such as lambda light chain (especially free light chain) disease, high-risk disease and probably extramedullary disease.

It could be argued that the increased TS in IOP patients was due to diminished transferrin level (i.e. TIBC) which is a negative acute phase protein. However, increased TS is not compatible with acute phase response. Additionally, serum iron level was frequently borderline high to increased in the IOP cohort which 
is not compatible with an acute phase response, too. ${ }^{14}$ There are very few studies focusing on iron in MM. Most investigations considered iron in the context of the anemia or acute phase reaction of MM.15-17 On the other hand, Song et al. ${ }^{4}$ studied the importance of serum ferritin in 89 patients with newly diagnosed MM. They observed that the overall survival in the elevated serum ferritin group was shorter than that in the normal serum ferritin group $(\mathrm{p}<0.001)$ after a median follow-up of 25 months. In their study, elevated ferritin was correlated with poor survival and was an independent predictor of mortality in MM $(p=0.002) .{ }^{4}$ They observed an association between increased ferritin level and advanced ISS stage. However, they did not report on other serum iron tests, possible mechanisms of elevated ferritin in MM patients and the association between serum iron parameters and type of myeloma. Those findings together with our iron results in this study cast attention to specifically search iron dynamics of MM in prospective controlled studies.

The iron status in MM may also be important for the long-term treatment response of the disease. Proteasome inhibition with bortezomib is a classical approach for the management of MM. The inhibition of proteasome functionality could affect cellular iron homeostasis and iron is a potent inducer of reactive oxygen species and cell death, unless safely stored in ferritin. ${ }^{5}$ Campanella and coworkers ${ }^{5}$ explored the potential role of iron in bortezomib-resistance. They analyzed iron proteins, oxidative status and cell viability in 7 multiple myeloma cell lines and in plasma cells from 5 patients. In their in vitro study, the cells were treated with increasing bortezomib concentrations with or without iron supplementation. The authors reduced ferritin levels via the molecular methods and by drug induced iron starvation. They observed that MM cell lines were characterized by distinct ferritin levels, which directly correlate with bortezomib resistance. ${ }^{5}$ Furthermore, iron supplementation upon bortezomib promoted proteins oxidation and cell death and that iron toxicity inversely correlates with basal ferritin levels. In their study, bortezomib prevented ferritin up-regulation in response to iron, thus limiting the ability to buffer reactive oxygen species. Accordingly, the authors suggested that the modulation of iron status is a strategy worth to be explored to improve the efficacy of proteasome inhibition therapies im MM. ${ }^{5}$ In our present study, four patients with responses $\geq$ VGPR showed complete improvement of the iron tests. Three cases with partial myeloma responses showed various responses in the iron tests. One had complete and 2 had partial improvements. Two patients with stable to progressive disease under treatment showed no improvement in the iron tests. Therefore, the long-term effects of current pharmacological myeloma therapies including bortezomib, thalidomide, and lenalidomide on iron status shall be prospectively searched.

Iron may also be important in the pathobiology of plasma cell neoplastic disorders. ${ }^{6-11}$ Ouellette et al.9 invented that iron in the presence of histidine enhanced cleavage of human immunoglobulin gamma (IgG) molecules containing a lambda light chain. Using molecular methods, they demonstrated that the cleavage resulted in elevated levels of free light and heavy chain fragments. ${ }^{9}$ Since iron has a significant role in the cleavage of lambda light chain IgG molecules $^{9}$, the close association between lambda light chain type paraproteinemia (especially free light chain) and IOP (13/17 in IOP cohort vs 26/73 lambda paraproteinemia, $\mathrm{p}=0.003$ ) in our present study could be important. Half of the MM patients (7/14) with free lambda light chain paraproteinemia had IOP in our patient cohort.

The searching of iron status may open new avenues in the treatment of MM. For instance, targeting the human transferrin receptor 1 (CD71) may be effective in the management of MM.6 Rodriguez and coworkers ${ }^{10}$ have developed recombinant antibodies targeting human transferrin receptor 1 , inducing receptor degradation and are cytotoxic to certain malignant B-cells. They showed that the internalization of transferrin receptor 1 bound to those antibodies can lead to its sequestration and degradation, as well as reduced transferrin uptake, and the induction of a transcriptional response consistent with iron deprivation, which is mediated in part by downstream targets of p53.10 Daniel et al. found that the cytotoxic effects of HXR9 can be enhanced by combining it with the antibody-avidin fusion protein specific for the human transferrin receptor $1(\mathrm{CD} 71) .^{7}$ Iron starvation induced by the fusion protein contributes to the enhanced effect and involves, at least in part, the induction of a caspase-independent pathway. In another in vitro study, Ciclopirox olamine (CPX) bound intracellular iron, and inhibited the iron-dependent enzyme ribonucleotide reductase at concentrations associated with cell death in myeloma.8 The underlying mechanisms and clinicopathological associations 
of IOP in MM should be further evaluated not only for academical purposes but also better future management of the patients.

In conclusion, serum iron tests compatible with iron overload is not infrequent in MM at diagnosis. These results are related to disease activity. IOP in MM has important clinical associations, such as lambda light chain disease, high-risk disease and probably extramedullary disease. The underlying mechanisms and its clinical associations should be further evaluated. Iron studies may open new ways in the management of MM.

\section{REFERENCES}

1. Savas MC, Benekli M, Haznedaroglu IC, Dundar SV. Bulky plasmacytoma of the skull with intracranial involvement. Am J Hematol 54: 173, 1997.

2. Serefhanoglu S, Haznedaroglu IC, Goker H, Buyukasik Y, Ozcebe OI. Multiple bulky cutaneous plasmacytomas with CNS relapse without bone marrow involvement during the course of a lambda light chain myeloma. Onkologie 32: 662664, 2009.

3. Serefhanoglu S, Sayinalp N, Haznedaroglu IC, et al. Extramedullary plasmacytomas of the thyroid and pericardium as initial presentation of multiple myeloma. Ann Hematol 87: 853-854, 2008.

4. Song MK, Chung JS, Seol YM, et al. Elevation of serum ferritin is associated with the outcome of patients with newly diagnosed multiple myeloma. Korean J Intern Med 24: 368-373, 2009.

5. Campanella A, Santambrogio P, Fontana F, et al. Iron increases the susceptibility of multiple myeloma cells to bortezomib. Haematologica 98: 971-979, 2013.

6. Daniels TR, Ortiz-Sanchez E, Luria-Perez R, et al. An antibody-based multifaceted approach targeting the human transferrin receptor for the treatment of B-cell malignancies. J Immunother 34: 500-508, 2011.

7. Daniels TR, Neacato II, Rodriguez JA, et al. Disruption of HOX activity leads to cell death that can be enhanced by the interference of iron uptake in malignant B cells. Leukemia 24: 1555-1565, 2010.

8. Eberhard $\mathrm{Y}, \mathrm{McDermott} \mathrm{SP}$, Wang $\mathrm{X}$, et al. Chelation of intracellular iron with the antifungal agent ciclopirox olamine induces cell death in leukemia and myeloma cells. Blood 114: 3064-1073, 2009.

9. Ouellette D, Alessandri L, Piparia R, et al. Elevated cleavage of human immunoglobulin gamma molecules containing a lambda light chain mediated by iron and histidine. Anal Biochem 389: 107-117, 2009.
10. Rodriguez JA, Luria-Perez R, Lopez-Valdes HE, et al. Lethal iron deprivation induced by non-neutralizing antibodies targeting transferrin receptor 1 in malignant B cells. Leuk Lymphoma 52: 2169-2178, 2011.

11. Suzuki E, Daniels TR, Helguera G, et al. Inhibition of NF-kap$\mathrm{paB}$ and Akt pathways by an antibody-avidin fusion protein sensitizes malignant B-cells to cisplatin-induced apoptosis. Int J oncol 36: 1299-3107, 2010.

12. Piperno A. Classification and diagnosis of iron overload. Haematologica 83: 447-455, 1998.

13. Buyukasik NS, Nadir I, Akin FE, et al. Serum iron parameters in cirrhosis and chronic hepatitis: detailed description. Turk J Gastroenterol 22: 606-611, 2011.

14. Wallach $J(E d)$. Interpretation of diagnostic tests. 8th edition. Philadelphia, Lippincott Williams and Wilkins, 2007: 270-271.

15. Haraguchi K, Uto H, Ohnou N, et al. Serum prohepcidin levels are potential prognostic markers in patients with multiple myeloma. Exp Ther Med 4: 581-588, 2012.

16. Katodritou E, Ganz T, Terpos E, et al. Sequential evaluation of serum hepcidin in anemic myeloma patients: study of correlations with myeloma treatment, disease variables, and anemia response. Am J Hematol 84: 524-526, 2009.

17. Maes K, Nemeth E, Roodman GD, et al. In anemia of multiple myeloma, hepcidin is induced by increased bone morphogenetic protein 2. Blood 116: 3635-3644, 2010.

\author{
Correspondence \\ Dr. Eylem ELIAÇIK \\ Hacettepe Üniversitesi Tıp Fakültesi \\ Hematoloji Anabilim Dalı \\ Sinhiye / ANKARA
}

Tel: (+90.312) 3051543

mail: eylemeli@gmail.com 